\title{
Kinetics of the Reactions of Laser-Flash Photolytically Generated Carbenium Ions with Alkyl and Silyl Enol Ethers. Comparison with the Reactivity toward Alkenes, Allylsilanes and Alcohols
}

\author{
Jörg Bartl, ${ }^{\dagger}$ Steen Steenken, ${ }^{*,}$ and Herbert Mayr ${ }^{*, \dagger}$ \\ Contribution from the Institut für Chemie, Medizinische Universität zu Lübeck, Ratzeburger \\ Allee 160, D-2400 Lübeck, Germany, and the Max-Planck-Institut für Strahlenchemie, D-4330 \\ Mülheim, Germany. Received March 28, 1991
}

\begin{abstract}
Diarylcarbenium ions (benzhydryl cations) are generated from diarylmethyl chlorides by 20 -ns laser pulses (248 $\mathrm{nm}$ ) in acetonitrile solution at $20^{\circ} \mathrm{C}$. The second-order rate constants for their reactions with $\mathrm{n}$ - and $\pi$-nucleophiles (anions, alcohols, water, alkenes, allylsilanes, alkyl and silyl enol ethers) are determined by monitoring the decay of the UV-vis transients at variable nucleophile concentrations. Only reactive nucleophiles $\left(k_{2}>10^{6}-10^{7} \mathrm{~L} \mathrm{~mol}^{-1} \mathrm{~s}^{-1}\right)$ can be investigated by this method because of the concomitant reactions of the carbenium ions with the solvent acetonitrile and the chloride ions produced in the photoheterolysis. The largest observed values of $k_{2}$ are $\sim 2 \times 10^{10}$ for reactions with anions and (2-4) $\times 10^{5} \mathrm{~L} \mathrm{~mol}^{-1} \mathrm{~s}^{-1}$ for reactions with neutral nucleophiles. Alkoxy-substituted ethylenes are 300-105 times more reactive than the corresponding alkyl-substituted ethylenes. The reactivities of structurally analogous alkyl and silyl enol ethers differ by less than 1 order of magnitude. In sharp contrast to the situation previously observed for the reactions of benzhydryl cations with alkenes, the nucleophilic reactivities of the enol ethers correlate with their ionization potentials and not with the stabilities of the carbenium ions produced in the rate-determining step. The rate constants measured for the reactions of the flash photolytically generated benzhydryl cations with alkenes and allylsilanes agree well with those extrapolated from the reactivities of these nucleophiles toward less electrophilic benzhydryl cations, which have previously been determined by conventional techniques. Combination of the two sets of data yields a nucleophilicity scale with respect to the reference electrophile $\left(p-\mathrm{H}_{3} \mathrm{CC}_{6} \mathrm{H}_{4}\right)_{2} \mathrm{CH}^{+}$.
\end{abstract}

\section{Introduction}

Although reactions of carbenium ions with alkyl and silyl enol ethers represent key steps of many synthetically important transformations, ${ }^{1}$ kinetic data for these reactions have, to our best knowledge, not yet been reported. Quantitative information on the nucleophilicity of these donor-substituted ethylenes has previously been derived from kinetic investigations of their acidcatalyzed hydrolyses, ${ }^{2}$ their cycloaddition rates toward electron deficient alkenes ${ }^{3}$ and dienes, ${ }^{4}$ and their low ionization potentials determined by photoelectron spectroscopy ${ }^{5}$ or UV-vis spectroscopy of CT complexes. ${ }^{6}$

We report now on the kinetics of the reactions of laser-flash photolytically generated diarylcarbenium ions ${ }^{7,8}$ toward alkyl and silyl enol ethers. For a comparison, we have also investigated some alkenes, allylsilanes, and n-nucleophiles under identical conditions. Since rate constants for the reactions of alkenes and allylsilanes with diarylcarbenium ions have previously been determined conventionally by monitoring the reaction sequence depicted in Scheme I, the two sets of data can be connected to give a more comprehensive nucleophilicity scale for $\pi$-systems with respect to carbenium electrophiles.

\section{Method}

Diarylchloromethanes were photolyzed with 20 -ns laser pulses ( 248 $\mathrm{nm}$ ) in acetonitrile solution as described previously, ${ }^{\text {,c }}$ to yield benzhydryl radicals and benzhydryl cations, which were detected by their UV-vis signals. In the presence of nucleophiles, the decay of the transient carbenium ion follows a first-order rate law (eq 1), and the second-order rate

$$
\begin{gathered}
-\mathrm{d}\left[\mathrm{Ar}_{2} \mathrm{CH}^{+}\right] / \mathrm{d} t=k_{\mathrm{obs}}\left[\mathrm{Ar}_{2} \mathrm{CH}^{+}\right] \\
k_{\mathrm{obb}}=k_{\mathrm{o}}+k_{2}[\mathrm{nuc}]
\end{gathered}
$$

constant $k_{2}$ can be derived from the slopes of $k_{\text {obu }}$ vs [nuc] plots (Figure 1). According to eq $2, k_{\text {ob }}$ incorporates $k_{0}$, the term for the reaction of $\mathrm{Ar}_{2} \mathrm{CH}^{+}$with the solvent acetonitrile, and $k_{2}[$ nuc], the pseudo-first-order term for the reaction of $\mathrm{Ar}_{2} \mathrm{CH}^{+}$with the nucleophiles ([nuc] $\gg$ $\left.\left[\mathrm{Ar}_{2} \mathrm{CH}^{+}\right]\right)$. Since the values of $k_{\mathrm{o}}$ range from $3 \times 10^{5}$ to $3 \times 10^{6} \mathrm{~s}^{-1}$ for

\footnotetext{
Labeck
}

¿Molheim.

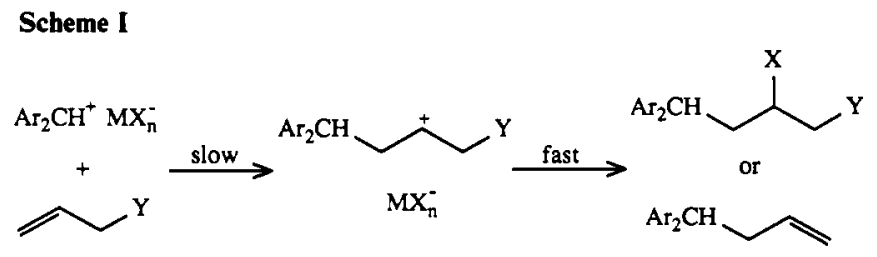

Table I. Second-Order Rate Constants $\left(k_{2}, \mathrm{~L} \mathrm{~mol}^{-1} \mathrm{~s}^{-1}\right)$ for the Reactions of Benzhydryl Cations with Anions in Acetonitrile at $20 \pm$ $1{ }^{\circ} \mathrm{C}$

\begin{tabular}{llc}
\hline & $\mathrm{Ph}_{2} \mathrm{CH}^{+}$ & $\left(p-\mathrm{H}_{3} \mathrm{COC}_{6} \mathrm{H}_{4}\right)_{2} \mathrm{CH}^{+}$ \\
\hline $\mathrm{F}^{-}$ & $2.0 \times 10^{10}$ & $1.4 \times 10^{10}$ \\
$\mathrm{Cl}^{-}$ & $2.0 \times 10^{10}$ & $1.5 \times 10^{10}$ \\
$\mathrm{Br}^{-}$ & $2.1 \times 10^{10}$ & $1.6 \times 10^{10}$ \\
$\mathrm{~J}^{-}$ & $1.9 \times 10^{10}$ & $1.6 \times 10^{10}$ \\
$\mathrm{SCN}^{-}$ & $2.7 \times 10^{10}$ & $1.4 \times 10^{10}$ \\
$\mathrm{SH}^{-}$ & $2.4 \times 10^{10}$ & \\
$\mathrm{H}_{2} \mathrm{PO}_{4}^{-}$ & $2.1 \times 10^{10}$ & $1.3 \times 10^{10}$ \\
$\mathrm{NO}_{2}^{-}$ & $2.2 \times 10^{10}$ & \\
$\mathrm{NO}_{3}^{-}$ & $2.1 \times 10^{10}$ & $2.5 \times 10^{9}$ \\
\hline
\end{tabular}

the carbenium ions used in this investigation, ${ }^{7 \mathrm{c}}$ only reactive nucleophiles with $k_{2}[$ nuc $] \geq 10^{7} \mathrm{~s}^{-1}$ can be studied by this method.

(1) (a) Reetz, M. T. Angew. Chem. 1982, 94, 97; Angew. Chem., Int. Ed. Engl. 1982, 2l, 96. (b) Mukaiyama, T. Org. React. (N.Y.) 1982, 28, 203. (c) Mukaiyama, T.; Murakami, M. Synthesis 1987, 1043. (d) Effenberger, F. Angew. Chem. 1969, 81, 374; Angew. Chem., Int. Ed. Engl. 1969, 8, 295. (e) Meerwein, H. Houben Weyl, Methoden der Organischen Chemie; Thieme: Stuttgart, 1965; Vol. VI-3, p 199. (f) Povarov, L. S. Russ. Chem. Rev. (Engl. Transl.) 1965, 34, 639. (g) Mathieu, J.; Weill-Raynal, J. Formation of C-C Bonds; Thieme: Stuttgart, 1979; Vol. III, p 196. (h) Makin, S. M. Russ. Chem. Rev. (Engl. Transl.) 1969, 38, 237. (i) Makin, S. M. Pure Appl. Chem. 1976, 47, 173 .

(2) (a) Knittel, P.; Tidwell, T. T. J. Am. Chem. Soc. 1977, 99, 3408. (b) Chwang, W. K.; Nowlan, V. J.; Tidwell, T. T. J. Am. Chem. Soc. 1977, 99, 7233. (c) Chwang, W. K.; Knittel, P.; Koshy, K. M.; Tidwell, T. T. J. Am. Chem. Soc. 1977, 99, 3395. (d) Kresge, A. J.; Chen, H. L.; Chiang, Y.; Murrill, E.; Payne, M. A.; Sagatys, D. S. J. Am. Chem. Soc. 1971, $93,413$. (e) Kresge, A. J.; Chwang, W. K. J. Am. Chem. Soc. 1978, 100, 1249. 


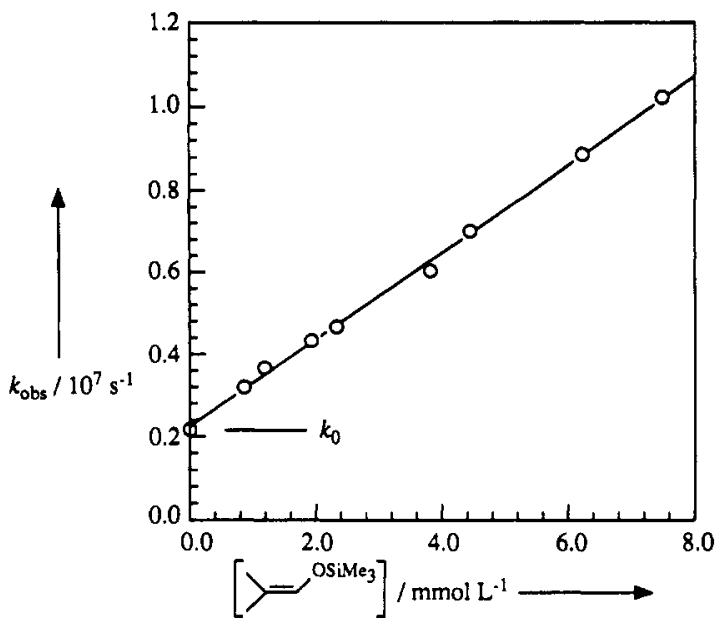

Figure 1. $k_{\text {obs }}$ vs concentration of nucleophile for the reaction of the parent diphenylcarbenium ion with silyl enol ether 29 in acetonitrile at $20 \pm 1^{\circ} \mathrm{C}\left(k_{2}=1.5 \times 10^{9} \mathrm{~L} \mathrm{~mol}^{-1} \mathrm{~s}^{-1}\right)$.

Table II. Pseudo-First-Order and Second-Order Rate Constants for the Reactions of the Benzhydryl Cation $\left(\mathrm{Ph}_{2} \mathrm{CH}^{+}\right)$with Various Nitriles (RC $\equiv N)$ Used as Solvents $\left(20 \pm 1^{\circ} \mathrm{C}\right)$

\begin{tabular}{cccc}
\hline $\mathrm{R}$ & $k_{\text {obu }}\left(\mathrm{s}^{-1}\right)$ & $\begin{array}{c}{[\mathrm{RC} \equiv \mathrm{N}]} \\
\left(\mathrm{mol} \mathrm{L}^{-1}\right)\end{array}$ & $\begin{array}{c}k_{2} \\
\left(\mathrm{~L} \mathrm{~mol}^{-1} \mathrm{~s}^{-1}\right)\end{array}$ \\
\hline $\mathrm{CH}_{3}$ & $(2.5 \pm 0.2) \times 10^{6}$ & 19.1 & $1.3 \times 10^{5}$ \\
$\mathrm{C}_{2} \mathrm{H}_{5}$ & $(7.2 \pm 0.1) \times 10^{6}$ & 14.0 & $5.1 \times 10^{5}$ \\
$i-\mathrm{C}_{3} \mathrm{H}_{7}$ & $(6.8 \pm 0.1) \times 10^{6}$ & 11.0 & $6.2 \times 10^{5}$ \\
$l-\mathrm{C}_{4} \mathrm{H}_{9}$ & $(6.1 \pm 0.1) \times 10^{6}$ & 9.06 & $6.7 \times 10^{5}$ \\
\hline
\end{tabular}

\section{Results and Discussion}

Anions. When the unsubstituted benzhydryl cation $\mathrm{Ph}_{2} \mathrm{CH}^{+}$ $\left(\mathrm{p} K_{\mathrm{R}^{+}}=-13.3\right)^{10}$ was generated in acetonitrile in the presence of the tetrabutylammonium salts of the anions listed in Table $I$, rate constants $k_{2}$ of approximately $2 \times 10^{10} \mathrm{~L} \mathrm{~mol}^{-1} \mathrm{~s}^{-1}$ were generally observed, indicating diffusion control for the reactions with anions." The same is true for the reactions of the highly stabilized carbenium ion $\left(p-\mathrm{MeOC}_{6} \mathrm{H}_{4}\right)_{2} \mathrm{CH}^{+}\left(\mathrm{p} K_{\mathrm{R}^{+}}=-5.71\right)^{10}$ with most anions, and a significantly lower value was only detected for the nitrate ion (Table I).

(3) (a) Huisgen, R.; Steiner, G. Tetrahedron Lett. 1973, 3763. (b) Huisgen, R.; Steiner, G. J. Am. Chem. Soc. 1973, 95 , 5056. (c) Huisgen, R. Acc. Chem. Res. 1977, 10,117. (d) Huisgen, R.; Schug, R. J. Chem. Soc., Chem. Commun. 1975, 59. (e) Huisgen, R.; Schug, R. J. Am. Chem. Soc. 1976, 98 , 7819.

(4) (a) Thalhammer, F.; Wallfahrer, U.; Sauer, J. Tetrahedron Lett. 1990 , 31,6851. (b) Meier, A.: Sauer, J. Tetrahedron Lett, 1990, 31, 6855.

(5) (a) Houk, K. N. Top. Curr. Chem. 1979, 79, 33. (b) Nelson, D. J.; Cooper, P. J.; Sondararajan, R. J. Am. Chem. Soc. 1989, 111, 1414. (c) Mayr, H. Dissertation, Universität München 1974.

(6) (a) Frey, J. E. Appl. Spectrosc. Rev. 1987, 23, 247. (b) Ledwith, A.; Woods, H. J. J. Chem. Soc. B 1970, 310.

(7) (a) McClelland, R. A.; Kanagasabapathy, V. M.; Steenken, S. J. Am. Chem. Soc. 1988, 110,6913 . (b) McCleliand, R. A.; Kanagasabapathy, V. M.; Banait, N.; Steenken, S. J. Am. Chem. Soc. 1989, 111 , 3966. (c) Bartl, J.; Steenken, S.; Mayr, H.; MeClelland, R. A. J. Am. Chem. Soc. 1990, 112, 6918.

(8) For laser-flash photolytic generation of other carbenium ions, see: (a) McClelland, R. A.; Banait, N.; Steenken, S. J. Am. Chem. Soc. 1986, 108 , 7023. (b) Kobayashi, S.; Kitamura, T.; Taniguchi, H.; Schnabel, W. Chem Lett. 1983, 1117. (c) Schnabel, W.; Naito, 1.; Kitamura, T.; Kobayashi, S. Taniguchi, H. Tetrahedron 1980, 36, 3229 . (d) Kobayashi, S.; Zhu, Q. Q.; Schnabel, W. Z. Naturforsch. 1988, 436, 825. (e) van Ginkel, F. I. M. . Visser,

R. J., Varma, C. A. G. O.; Lodder, G. J. Photochem. 1985, 30, 453.

(9) (a) Mayr, H.; Schneider, R.; Schade, C.; Bartl, J.; Bederke, R. J. Am. Chem. Soc. 1990, I12, 4446. (b) Mayr, H.; Schneider, R.; Irrgang, B. Schade, C.; J. Am. Chem. Soc. 1990, 112, 4454. (c) Mayr, H.; Schneider, R.; Grabis, U.; J. Am. Chem. Soc. 1990, 112, 4460. (d) Irrgang, B.; Mayr, H. Tetrahedron 1991, 47, 219. (c) Hagen, G.; Mayr, H. J. Am. Chem. Soc. 1991, 113, 4954. (f) Review: Mayr, H. Angew. Chem. 1990, 102, 1415 Angew. Chem., Int. Ed. Engl. 1990, 29, 1371.

(10) (a) Deno, N. C.; Jaruzelski, J.; Schriesheim, A. J. Am. Chem. Soc 1955, 77, 3044. (b) Deno, N. C.; Schriesheim, A. J. Am. Chem. Soc. 1955 77, 3051. (c) Deno, N. C.; Evans, W. L. J. Am. Chem. Soc. 1957, 79, 5804. (11) For a discussion of diffusion-controlled reactions of benzhydryl and trityl cations, see: McClelland, R. A.; Kanagasabapathy, V. M.; Banait, N. S.; Steenken, S. J. Am. Chem. Soc. 1991, 113, 1009.
Table III. Second-Order Rate Constants $\left(\mathrm{L} \mathrm{mol}^{-1} \mathrm{~s}^{-1}\right)$ for the Reactions of Carbenium Ions with Water and Alcohols in Acetonitrile $(>98.5 \%)$ at $20^{\circ} \mathrm{C}$

\begin{tabular}{lccc}
\hline nucleophile & $\left(p-\mathrm{ClC}_{6} \mathrm{H}_{4}\right)_{2} \mathrm{CH}^{+}$ & $\mathrm{Ph}_{2} \mathrm{CH}^{+}$ & $\mathrm{An}_{2} \mathrm{C}=\mathrm{C}^{+} \mathrm{An}^{\mathrm{a}, 6}$ \\
\hline $\mathrm{H}_{2} \mathrm{O}$ & $1.7 \times 10^{8}$ & $1.2 \times 10^{8}$ & $5.5 \times 10^{4}$ \\
$\mathrm{MeOH}$ & $1.1 \times 10^{9}$ & $1.2 \times 10^{9}$ & $3.8 \times 10^{5}$ \\
$\mathrm{EtOH}$ & $1.1 \times 10^{9}$ & $8.5 \times 10^{8}$ & $3.2 \times 10^{5}$ \\
$i=\mathrm{PrOH}$ & $4.1 \times 10^{8}$ & $3.1 \times 10^{8}$ & $1.2 \times 10^{5}$ \\
$t$ - $\mathrm{BuOH}$ & $1.4 \times 10^{8}$ & $6.9 \times 10^{7}$ & $1.8 \times 10^{4}$ \\
\hline
\end{tabular}

${ }^{a} \mathrm{An}=p-\mathrm{H}_{3} \mathrm{COC}_{6} \mathrm{H}_{4},{ }^{b}$ Reference 8b,d.

Table IV. Second-Order Rate Constants $\left(\mathrm{L} \mathrm{mol}^{-1} \mathrm{~s}^{-1}\right)$ for the Reactions of para-Substituted Benzhydryl Cations with Ethanol and Water in Acetonitrile at $20^{\circ} \mathrm{C}$

\begin{tabular}{lccc}
\hline $\begin{array}{c}\text { para } \\
\text { substituents }\end{array}$ & EtOH & $\mathrm{H}_{2} \mathrm{O}$ & $\begin{array}{c}\text { ethanolysis }^{a} \\
\left(\log k_{\text {solv }}, 25^{\circ} \mathrm{C}\right)\end{array}$ \\
\hline $\mathrm{Cl}, \mathrm{Cl}$ & $1.1 \times 10^{9}$ & $1.7 \times 10^{8}$ & -5.093 \\
$\mathrm{Cl}, \mathrm{H}$ & $8.9 \times 10^{8}$ & & -4.686 \\
$\mathrm{H}, \mathrm{H}$ & $8.5 \times 10^{8}$ & $1.2 \times 10^{8 b}$ & -4.271 \\
$\mathrm{~F}, \mathrm{H}$ & $5.0 \times 10^{8}$ & & -4.032 \\
$\mathrm{~F}, \mathrm{~F}$ & $4.4 \times 10^{8}$ & & \\
$\mathrm{Me}, \mathrm{H}$ & $2.0 \times 10^{8}$ & $1.7 \times 10^{7 c}$ & -2.910 \\
$\mathrm{Me}, \mathrm{Me}$ & $5.0 \times 10^{7}$ & $4.3 \times 10^{6 c}$ & -1.694 \\
\hline
\end{tabular}

${ }^{a}$ Ethanolysis rate constants of $\mathrm{ArAr}^{\prime} \mathrm{CHCl}$ from ref $13 .{ }^{b} 1.3 \times 10^{8}$, ref $7 b$. ${ }^{c}$ From ref $7 b$.

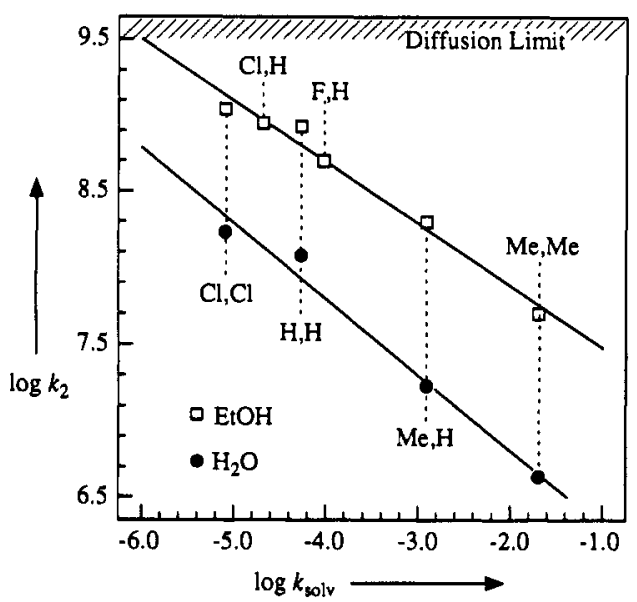

Figure 2. Correlation of the reactivity of benzhydryl cations (para substituents in graph) toward ethanol and water $\left(20^{\circ} \mathrm{C}\right.$, acetonitrile) with the ethanolysis rate constants $\left(25^{\circ} \mathrm{C}\right)$ of the corresponding benzhydryl chlorides: EtOH, $\log k_{2}=-0.405 \log k_{\text {wolv }}+7.07 ; \mathrm{H}_{2} \mathrm{O}, \log k_{2}=-0.495$ $\log k_{\text {solv }}+5.82$.

These findings agree with Dorfman's report that $\mathrm{Ph}_{2} \mathrm{CH}^{+}$and $\mathrm{Ph}_{3} \mathrm{C}^{+}$combine with halide ions $\left(\mathrm{Cl}^{-}, \mathrm{Br}^{-}, \mathrm{I}^{-}\right)$with rate constants of $(3-9) \times 10^{10}$, the diffusion limit in 1,2-dichloroethane. ${ }^{12 a-d}$ For the reaction of $\mathrm{Cl}^{-}$with the structurally related $p$-anisyl- $\alpha$ naphthylcarbenium ion in acetonitrile/water $(95 / 5)$, a rate constant clearly below the diffusion limit $\left(k_{2}=2.2 \times 10^{9} \mathrm{~L} \mathrm{~mol}^{-1}\right.$ $\mathrm{s}^{-1}$ ) was found, while diffusion control was observed for the reaction of this cation with $\mathrm{N}_{3}^{-}\left(k_{2}=1.8 \times 10^{10} \mathrm{~L} \mathrm{~mol}^{-1} \mathrm{~s}^{-1}\right)$. ${ }^{12 \mathrm{e}}$ In acetonitrile/water (1/2), the trityl cation reacts with $\mathrm{Cl}^{-}$and $\mathrm{Br}^{-}$ with rate constants of $2.2 \times 10^{6}$ and $5 \times 10^{6} \mathrm{~L} \mathrm{~mol}^{-1} \mathrm{~s}^{-1}$, respectively. ${ }^{8 a}$ Only carbenium ions with low electrophilicity, such as the $1-(p$-anisyl)-2,2-diphenylvinyl cation, have been reported to undergo activation-controlled reactions with anions as $\mathrm{Br}^{-}$and $\mathrm{CH}_{3} \mathrm{CO}_{2}^{-}$in pure acetonitrile. ${ }^{8 \mathrm{e}}$

Nitriles. Pseudo-first-order rate constants from $3.5 \times 10^{5} \mathrm{~s}^{-1}$ $\left[\left(p-\mathrm{H}_{3} \mathrm{CC}_{6} \mathrm{H}_{4}\right)_{2} \mathrm{CH}^{+}\right]$to $3.8 \times 10^{7} \mathrm{~s}^{-1}\left[\left(p-\mathrm{F}_{3} \mathrm{CC}_{6} \mathrm{H}_{4}\right) \mathrm{PhCH}^{+}\right]$have

(12) (a) Dorfman, L. M.; Sujdak, R.; Bockrath, B. Acc. Chem. Res. 1976 9, 352. (b) Kundu, K. P.; Dorfman, L. M. Radiat. Phys. Chem. 1982, 20 247. (c) Sujdak, R. J.; Jones, R. L.; Dorfman, L. M. J. Am. Chem. Soc. 1976, 98, 4875. (d) Dorfman, L. M.; Wang, Y.; Wang, H.-Y.; Sujdak, R. J. Faraday Discuss. Chem. Soc. 1977, 63, 149. (e) Alonso, E. O.; Johnston, L. J.; Scaiano, J. C.; Toscano, V. G. J. Am. Chem. Soc. 1990, 112, 1270.

(13) Schade, C.; Mayr, H. Tetrahedron 1988, 44, 5761. 
Table V. Second-Order Rate Constants for the Reactions of Benzhydryl Cations with $\pi$-Nucleophiles in Acetonitrile at $20^{\circ} \mathrm{C}$

\begin{tabular}{|c|c|c|c|c|c|c|}
\hline & nucleophile & $\left(p-\mathrm{ClC}_{6} \mathrm{H}_{4}\right)_{2} \mathrm{CH}^{+}$ & $\left(p-\mathrm{CH}_{3} \mathrm{C}_{6} \mathrm{H}_{4}\right)_{2} \mathrm{CH}^{+}$ & nucleophile & $\left(p-\mathrm{ClC}_{6} \mathrm{H}_{4}\right)_{2} \mathrm{CH}^{+}$ & $\left(p \cdot \mathrm{CH}_{3} \mathrm{C}_{6} \mathrm{H}_{4}\right)_{2} \mathrm{CH}^{+}$ \\
\hline \multicolumn{7}{|c|}{ Alkenes } \\
\hline 1 & & $9.8 \times 10^{6}$ & 5 & & $6.0 \times 10^{7}$ & $1.4 \times 10^{6}$ \\
\hline 2 & & $1.0 \times 10^{7}$ & 6 & & $8.5 \times 10^{7}$ & $1.3 \times 10^{6}$ \\
\hline 3 & & $7.3 \times 10^{7}$ & 7 & & $1.6 \times 10^{7}$ & \\
\hline 4 & & $8.9 \times 10^{7}$ & 8 & & $\sim 1 \times 10^{7}$ & \\
\hline \multicolumn{7}{|c|}{ Allylsilanes } \\
\hline 9 & & $1.8 \times 10^{7}$ & 12 & & $2.2 \times 10^{9}$ & \\
\hline 10 & & $6.7 \times 10^{8}$ & & & & \\
\hline 11 & & $5.8 \times 10^{8}$ & 13 & & $1.4 \times 10^{8}$ & $1.9 \times 10^{6}$ \\
\hline \multicolumn{7}{|c|}{ Alkyl Vinyl Ethers } \\
\hline 14 & & $1.7 \times 10^{8}$ & $6.3 \times 10^{6}$ & & $2.2 \times 10^{9}$ & $2.2 \times 10^{8}$ \\
\hline 15 & $8 u)$ & $2.0 \times 10^{8}$ & 22 & & $27 \times 10^{8}$ & \\
\hline 16 & & $1.9 \times 10^{8}$ & & & & \\
\hline 17 & $B \cup)$ & $4.2 \times 10^{8}$ & 23 & & $1.3 \times 10^{9}$ & \\
\hline 18 & & $7.4 \times 10^{8}$ & $3.7 \times 10^{7}$ & & $3.5 \times 10^{9}$ & $1.2 \times 10^{8}$ \\
\hline 19 & & $7.7 \times 10^{8}$ & & & & \\
\hline 20 & & $1.3 \times 10^{9}$ & 25 & & $1.9 \times 10^{9}$ & $2.2 \times 10^{8}$ \\
\hline & & & 26 & & $\sim 4 \times 10^{9}$ & \\
\hline \multicolumn{7}{|c|}{ Silyl Enol Ethers and Ketene Acetals } \\
\hline 27 & & $5.5 \times 10^{7}$ & 31 & & $2.5 \times 10^{9}$ & $6.0 \times 10^{8}$ \\
\hline 28 & & $2.1 \times 10^{8}$ & 32 & & $2.3 \times 10^{9}$ & $1.3 \times 10^{8}$ \\
\hline & & & 33 & & $1.4 \times 10^{9}$ & $1.1 \times 10^{8}$ \\
\hline 29 & & $1.5 \times 10^{9}$ & $4.2 \times 10^{7}$ & & & \\
\hline 30 & & $3.0 \times 10^{9}$ & 34 & & $2.4 \times 10^{9}$ & \\
\hline
\end{tabular}

been reported for the reactions of various benzhydryl cations with the solvent acetonitrile. ${ }^{\text {tc }}$ The Eyring activation parameters $\Delta H^{*}$ $=11.6 \mathrm{~kJ}$ and $\Delta S^{*}=-105 \mathrm{~J} \mathrm{~K}^{-1} \mathrm{~mol}^{-1}$ have now been determined for the reaction of $\mathrm{Ph}_{2} \mathrm{CH}^{+}$with acetonitrile by measuring the decay rate in the temperature range $0-50^{\circ} \mathrm{C}$.

Propionitrile $(\mathrm{R}=\mathrm{Et})$ shows a 4 times greater nucleophilicity toward $\mathrm{Ph}_{2} \mathrm{CH}^{+}$than acetonitrile, but branching of the alkyl group increases the addition rates only slightly (Table II).

Water and Alcohols. In acetonitrile $(>98.5 \%)$, perfect second-order kinetics are observed for the reactions of water and alcohols with the benzhydryl cation $\left(\mathrm{Ph}_{2} \mathrm{CH}^{+}\right)$, in contrast to the situation in 1,2-dichloroethane solvent, where partial dimerizations of these nucleophiles cause complications. ${ }^{12 a-d}$ The nucleophilicity of the alcohols decreases with increasing branching of the alkyl group, and water ranges between isopropyl alcohol and tert-butyl alcohol. As shown in Table III, this is exactly the same nucleophilicity order as previously reported for the tris( $p$-anisyl)vinyl cation. ${ }^{8 b, d}$ The different reactivity order for alcohols in 1,2-dichloroethane ${ }^{12 c}$ is probably due to the fact that partial dimerization of the alcohols in this solvent gives rise to a more complicated kinetic scheme, from which the reactivities of the monomers are not easily derived.
Table IV and Figure 2 show that the reactivities of the benzhydryl cations with water and ethanol correlate with the ethanolysis rate constants of the corresponding benzhydryl chlorides, which may be considered a measure for carbocation stability. The slightly smaller slope of the ethanol correlation is possibly due to the fact that these rate constants approach the diffusion limit.

Alkenes and Allylsilanes. The relative nucleophilicities of terminal vinyl compounds have previously been reported to be independent of the electrophilicity of the reference benzhydryl cation. ${ }^{9 c}$ Since these reactions are, furthermore, characterized by similar activation entropies, it is not surprising that the same reactivity order that has been reported for the reactions of terminal vinyl derivatives with $\left(p-\mathrm{CH}_{3} \mathrm{OC}_{6} \mathrm{H}_{4}\right) \mathrm{PhCH}^{+}$at $-70^{\circ} \mathrm{C}^{9}$ is now observed for the reactions of these nucleophiles with ( $p$ $\left.\mathrm{ClC}_{6} \mathrm{H}_{4}\right)_{2} \mathrm{CH}^{+}$at $20^{\circ} \mathrm{C}$ :

$$
1 \sim 2 \sim 8<9<5<10
$$

Considerable deviations from the previously reported reactivity orders are observed, however, when nonterminal double-bonded compounds are included: According to Table $V$, tetramethylethylene (4) is 9 times more reactive than 2-methyl-1-pentene (1), in contrast to the reactivity ratio $k(4): k(1)=1: 4.5$, which has 
Table VI. Rate Constants for the Reactions of para,para'-Substituted Benzhydryl Cations with Methylenecyclopentane at $20^{\circ} \mathrm{C}$

\begin{tabular}{|c|c|c|c|}
\hline solvent & para,para' substituents & $\begin{array}{l}k_{\mathrm{H}_{2} \mathrm{O}^{a}} \\
\left(\mathrm{~s}^{-1}\right)\end{array}$ & $\begin{array}{c}k_{2} \\
\left(\mathrm{~L} \mathrm{~mol}^{-1} \mathrm{~s}^{-1}\right)\end{array}$ \\
\hline $\begin{array}{l}\mathrm{CH}_{3} \mathrm{CN} \\
\mathrm{CH}_{3} \mathrm{CN} \\
\mathrm{CH}_{3} \mathrm{CN} \\
\mathrm{CH}_{3} \mathrm{CN} \\
\mathrm{CH}_{2} \mathrm{Cl} \\
\mathrm{CH}_{2} \mathrm{Cl}_{2} \\
\mathrm{CH}_{2} \mathrm{Cl}_{2} \\
\mathrm{CH}_{2} \mathrm{Cl}_{2}\end{array}$ & $\begin{array}{l}\mathrm{Cl}, \mathrm{Cl} \\
\mathrm{H}, \mathrm{H} \\
\mathrm{Me}, \mathrm{H} \\
\mathrm{Me}, \mathrm{Me} \\
\mathrm{OPh}, \mathrm{H} \\
\mathrm{OMe}, \mathrm{H} \\
\mathrm{OMe}, \mathrm{Me} \\
\mathrm{OMe}, \mathrm{OMe}\end{array}$ & $\begin{array}{l}9 \times 10^{8} \\
1.2 \times 10^{8} \\
3.2 \times 10^{7} \\
2.1 \times 10^{6} \\
9.1 \times 10^{5} \\
1.3 \times 10^{5}\end{array}$ & $\begin{array}{l}6.0 \times 10^{7} \\
5.3 \times 10^{7} \\
7.6 \times 10^{6} \\
1.4 \times 10^{6} \\
1.3 \times 10^{5 b} \\
2.0 \times 10^{4 c} \\
6.1 \times 10^{3 b} \\
3.0 \times 10^{2 b} \\
\end{array}$ \\
\hline
\end{tabular}

${ }^{a}$ Reaction with $\mathrm{H}_{2} \mathrm{O}$ in $\mathrm{H}_{2} \mathrm{O} /$ acetonitrile $=2 / 1$, ref $7 \mathrm{~b}$. ${ }^{b}$ From $k_{2}$ $\left(-70^{\circ} \mathrm{C}\right.$ ) assuming $\Delta S^{*}=-123 \mathrm{~J} \mathrm{~mol}^{-1} \mathrm{~K}^{-1}$ (see text). ${ }^{c}$ Extrapolated from experiments at -40 to $-80^{\circ} \mathrm{C}$.

been measured with respect to $\left(p-\mathrm{CH}_{3} \mathrm{OC}_{6} \mathrm{H}_{4}\right) \mathrm{PhCH}^{+}$at $-70^{\circ} \mathrm{C} .9^{9}$ Analogously, compounds 10 and 11 show a similar reactivity toward $\left(p-\mathrm{ClC}_{6} \mathrm{H}_{4}\right)_{2} \mathrm{CH}^{+}$at $20^{\circ} \mathrm{C}$ (Table V), whereas 10 has been reported to be 2 orders of magnitude more reactive than 11 toward $\left(p-\mathrm{CH}_{3} \mathrm{OC}_{6} \mathrm{H}_{4}\right) \mathrm{PhCH}^{+}$at $-70{ }^{\circ} \mathrm{C}$. 9 These deviations are a consequence of the more negative activation entropies for nonterminal vinyl systems and of the different sensitivity of terminal and nonterminal $\pi$-systems to electrophile variations. ${ }^{9 c}$ As the relationships between structure and reactivity have already been discussed in detail for these classes of compounds, ${ }^{9}$ we will now concentrate on the comparison of rate constants determined by the different methods.

In a previous paper, we have reported rate constants for the reactions of four differently substituted carbenium salts $\mathrm{Ar}_{2} \mathrm{CH}^{+} \mathrm{BCl}_{4}^{-}$with methylenecyclopentane (5) in $\mathrm{CH}_{2} \mathrm{Cl}_{2}$ at -70 ${ }^{\circ} \mathrm{C} .9 \mathrm{c}$ We have now measured the rates of the reactions of this nucleophile (5) with four additional benzhydryl cations generated by laser flash photolysis in acetonitrile at $20^{\circ} \mathrm{C}$ (Table VI).

In order to convert the published $k_{2}\left(-70^{\circ} \mathrm{C}\right)$ values ${ }^{9 \mathrm{c}}$ to 20 ${ }^{\circ} \mathrm{C}$, we take advantage of the fact that $\Delta S^{*}$ for the reactions of benzhydryl cations with various $\pi$-nucleophiles is generally constant within a reaction series, $, c, e$ i.e., when only the $p$-substituents of the carbenium ions are altered. The activation entropy determined for the reaction of $\left(p-\mathrm{CH}_{3} \mathrm{OC}_{6} \mathrm{H}_{4}\right) \mathrm{PhCH}^{+}$with methylenecyclopentane $5\left(\Delta S^{*}=-123 \mathrm{~J} \mathrm{~mol}^{-1} \mathrm{~K}^{-1}\right)$ can, therefore, be combined with the rate constants measured at $-70{ }^{\circ} \mathrm{C}$ to calculate $k_{2}\left(20^{\circ} \mathrm{C}\right)$ for the lower four entries of Table VI. Now, the rate constants for the reactions of the benzhydryl cations with methylenecyclopentane $\mathbf{5}$, determined by two different methods, can be plotted against the corresponding rate constants for water to give a linear correlation (Figure 3), which proves the mutual consistency of the two methods. A correction for the use of different solvents has not been carried out, since the rate ratio $k$ (acetonitrile) $/ k\left(\mathrm{CH}_{2} \mathrm{Cl}_{2}\right)$ can be derived to be relatively small (factor 3). ${ }^{9 \mathrm{a}}$

Equation 3 has been reported to correlate the reactivities of benzhydryl cations toward alkenes and allylelement compounds $\left(\mathrm{CH}_{2} \mathrm{Cl}_{2},-70^{\circ} \mathrm{C}\right)$ with the ethanolysis rate constants of the corresponding benzhydryl chlorides. For several alkenes and allylelement compounds, $s$ and $c$ values have been listed. ${ }^{9 c, e}$ As

$\log k_{2}\left(203 \mathrm{~K}, \mathrm{CH}_{2} \mathrm{Cl}_{2}\right)=-1.26 s \log k_{\text {solv }}+0.90 s+c$

eq 3 refers to isoentropic reaction series, ${ }^{14}$ it can be adjusted to different temperatures by multiplying the slope with $203 / T$ (eq 4). The temperature-dependent nucleophilicity parameters const for the nucleophiles listed in Table VII have been calculated by the following procedure. From the known activation parameters for the reactions of $\left(p-\mathrm{H}_{3} \mathrm{COC}_{6} \mathrm{H}_{4}\right) \mathrm{PhCH}^{+}$with these nucleophiles, one can derive $\log k_{2}\left(\mathrm{CH}_{2} \mathrm{Cl}_{2}, 20^{\circ} \mathrm{C}\right)$, as listed in column 3 of Table VII. Since eq 4 also refers to $\left(p-\mathrm{H}_{3} \mathrm{COC}_{6} \mathrm{H}_{4}\right) \mathrm{PhCH}^{+}$,

$$
\log k_{2}\left(T, \mathrm{CH}_{2} \mathrm{Cl}_{2}\right)=-256 \mathrm{~s} / T \log k_{\text {solv }}+\text { const }
$$

the parameters const $\left(20^{\circ} \mathrm{C}\right)$ listed in column 4 have been obtained

(14) $\Delta S^{*}$ remains constant, when the substitution of the benzhydryl cation is altered (ref $9 c)$.

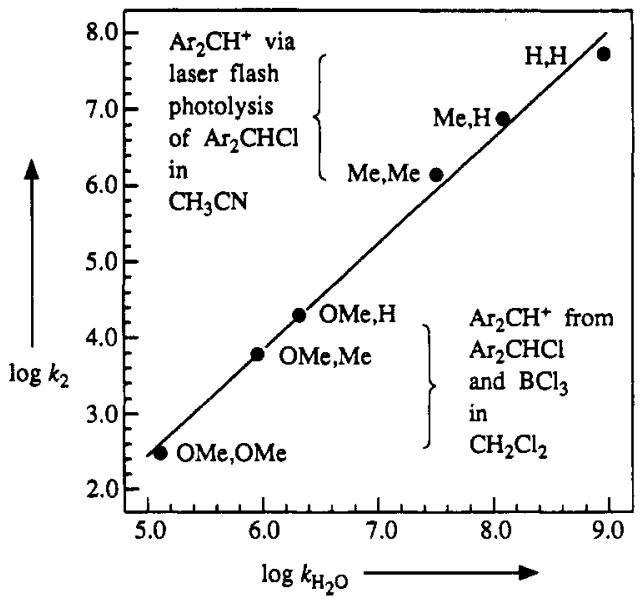

Figure 3. Correlation of the reactivities of benzhydryl cations (para substituents in graph) toward methylenecyclopentane (5) at $20^{\circ} \mathrm{C}$ with the corresponding reactivities toward $\mathrm{H}_{2} \mathrm{O}\left(k_{\mathrm{H}_{2} \mathrm{O}}\right.$ in $\mathrm{H}_{2} \mathrm{O}$ /acetonitrile $=$ $\left.2 / 1 ; \mathrm{s}^{-1}\right) ;^{7 \mathrm{~b}} \log k_{2}=1.397 \log k_{\mathrm{H}_{2} \mathrm{O}}-4.55$.

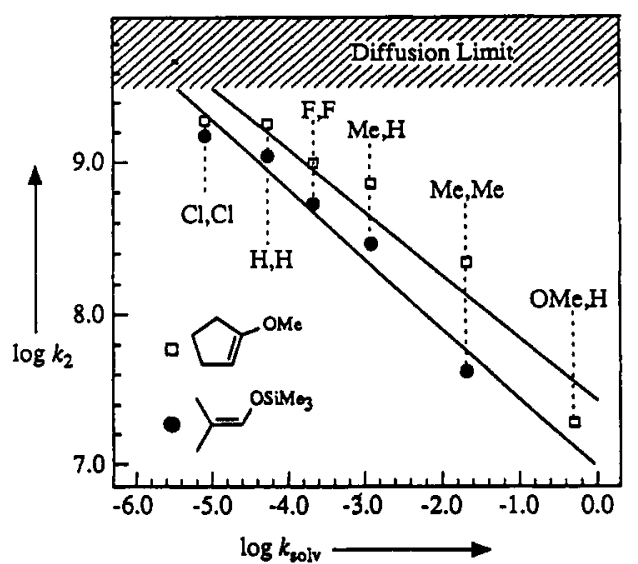

Figure 4. Correlation of the reactivities of benzhydryl cations (para substituents in graph) toward 1-cyclopentenyl methyl ether (25) and 2-methyl-1-(trimethylsiloxy)-1-propene (29) with the ethanolysis rate constants $\left(25^{\circ} \mathrm{C}\right)$ of the corresponding benzhydryl chlorides.

from $\propto q 4$ by filling in the $\log k_{2}$ values (column 3 ), the ethanolysis rate constant of $p$-methoxybenzhydryl chloride $\left(\log k_{\text {solv }}=-0.301\right.$; ref 13$), s$ (column 2$)$, and $T(293 \mathrm{~K})$. Now, the rates of addition of all benzhydryl cations (of known $\log k_{\text {solv }}$ ) to the nucleophiles listed in Table VII can be calculated from eq 4. Calculated addition rate constants for $\left(p-\mathrm{ClC}_{6} \mathrm{H}_{4}\right)_{2} \mathrm{CH}^{+}$are listed in column 5 of Table VII.

Comparison of the rate constants thus extrapolated $\left(\mathrm{CH}_{2} \mathrm{Cl}_{2}\right.$, column 5, Table VII) with the corresponding experimental value $\left(\mathrm{CH}_{3} \mathrm{CN}\right.$, right column) shows deviations by less than a factor of 4 , a satisfactory agreement, when the crude method of extrapolation is considered. A direct comparison of the rate constants determined in this work with the previously published reactivity data ${ }^{9}$ is, thus, possible. Including the earlier results of competition experiments, ${ }^{15}$ there are now three independent sources of kinetic data for the reactions of carbenium ions with $\pi$-nucleophiles, all of which are in mutual agreement.

Alkyl and Silyl Enol Ethers. While most of the compounds 14-34 have only been studied with one or two benzhydryl cations (Table V), the relationship between addition rate constants and structure of the carbenium ions has systematically been investigated with compounds 29,25 , and 32 (Table VIII). Figure 4 demonstrates that, also for highly reactive systems $\left(k_{2}=10^{7}-10^{9}\right.$ $\left.\mathrm{L} \mathrm{mol}^{-1} \mathrm{~s}^{-1}\right)$, a correlation between electrophilic reactivity and the stabilization of the benzhydryl cations (expressed by the corresponding solvolysis rates) exists. While the paucity of data

(15) (a) Mayr, H.; Pock, R. Chem. Ber, 1986, 119, 2473. (b) Pock, R. Mayr, H. Chem. Ber. 1986, 1/9, 2497. (c) Mayr, H.; Pock, R. Tetrahedron 1986, 42, 4211. 
Table VII. Comparison of Extrapolated (Column 5) and Experimental (Colunm 6) Rate Constants for the Reactions of Several Nucleophiles with the Bis(p-chlorophenyl)carbenium Ion $\left(20^{\circ} \mathrm{C}\right)$

\begin{tabular}{|c|c|c|c|c|c|}
\hline \multirow[b]{2}{*}{ nucleophile } & \multirow[b]{2}{*}{$s^{a}$} & \multirow[b]{2}{*}{$\begin{array}{c}\log k_{2}\left[\left(p-\mathrm{CH}_{3} \mathrm{OC}_{6} \mathrm{H}_{4}\right) \mathrm{PhCH}^{+}\right] \\
\left(\mathrm{CH}_{2} \mathrm{Cl}_{2}, 20^{\circ} \mathrm{C}\right)^{b}\end{array}$} & \multirow[b]{2}{*}{$\begin{array}{l}\text { const }^{c} \\
\left(20^{\circ} \mathrm{C}\right)\end{array}$} & \multicolumn{2}{|c|}{$k_{2}\left[\left(p-\mathrm{ClC}_{6} \mathrm{H}_{4}\right)_{2} \mathrm{CH}^{+}\right]$} \\
\hline & & & & $\begin{array}{l}\left(\mathrm{CH}_{2} \mathrm{Cl}_{2}\right. \\
\left.20^{\circ} \mathrm{C}\right)^{\mathrm{c}}\end{array}$ & $\begin{array}{l}\left(\mathrm{CH}_{3} \mathrm{CN},\right. \\
\left.20^{\circ} \mathrm{C}\right)^{d}\end{array}$ \\
\hline 1 & 1.00 & 3.098 & 2.835 & $1.9 \times 10^{7}$ & $9.8 \times 10^{6}$ \\
\hline 3 & 1.164 & 3.143 & 2.837 & $1.0 \times 10^{8}$ & $7.3 \times 10^{7}$ \\
\hline 4 & 1.394 & 1.539 & 1.173 & $2.4 \times 10^{7}$ & $8.9 \times 10^{7}$ \\
\hline 5 & 0.948 & 4.310 & 4.061 & $1.9 \times 10^{8}$ & $6.0 \times 10^{7}$ \\
\hline 7 & 1.106 & 2.497 & 2.206 & $1.3 \times 10^{7}$ & $1.6 \times 10^{7}$ \\
\hline 8 & 0.977 & 3.164 & 2.907 & $1.8 \times 10^{7}$ & $\sim 1 \times 10^{7}$ \\
\hline 9 & 0.950 & 3.651 & 3.401 & $4.2 \times 10^{7}$ & $1.8 \times 10^{7}$ \\
\hline 11 & 1.217 & 5.583 & 3.264 & $4.7 \times 10^{8}$ & $5.8 \times 10^{8}$ \\
\hline
\end{tabular}

${ }^{a}$ Reference 9 c,e. ${ }^{b}$ Calculated from activation parameters given in ref 9 . ' $\mathrm{c}$ For method of calculation, see text. ${ }^{d}$ Experimental data, this work.

Table VIII. Second-Order Rate Constants $\left(k_{2}, \mathrm{~L} \mathrm{~mol}^{-1} \mathrm{~s}^{-1}\right)$ for the Reactions of para-Substituted Benzhydryl Cations with Alkyl and Silyl Enol Ethers in Acetonitrile at $20^{\circ} \mathrm{C}$

\begin{tabular}{lccc}
\hline $\begin{array}{c}\text { para } \\
\text { substituents }\end{array}$ & $\mathbf{2 9}$ & $\mathbf{2 5}$ & $\mathbf{3 2}$ \\
\hline $\mathrm{Cl}, \mathrm{Cl}$ & $1.5 \times 10^{9}$ & $1.9 \times 10^{9}$ & $2.3 \times 10^{9}$ \\
$\mathrm{H}, \mathrm{H}$ & $1.1 \times 10^{9}$ & $1.8 \times 10^{9}$ & $1.6 \times 10^{9}$ \\
$\mathrm{~F}, \mathrm{~F}$ & $5.3 \times 10^{8}$ & $9.9 \times 10^{8}$ & $7.5 \times 10^{8}$ \\
$\mathrm{Me}, \mathrm{H}$ & $2.9 \times 10^{8}$ & $7.2 \times 10^{8}$ & $4.9 \times 10^{8}$ \\
$\mathrm{Me}, \mathrm{Me}$ & $4.2 \times 10^{7}$ & $2.2 \times 10^{8}$ & $1.3 \times 10^{8}$ \\
OMe, H & & $1.9 \times 10^{7}$ & $1.9 \times 10^{7}$ \\
\hline
\end{tabular}

Chart I. Relative Reactivities toward $\left(p-\mathrm{MeC}_{6} \mathrm{H}_{4}\right)_{2} \mathrm{CH}^{+}\left(20^{\circ} \mathrm{C}\right)$

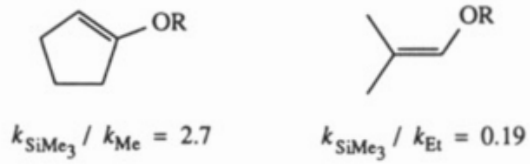

prevents a definitive interpretation, it appears as if the slopes of the $\log k_{2} / \log k_{\text {solv }}$ correlations decrease as $k_{2}$ exceeds $10^{8} \mathrm{~L} \mathrm{~mol}^{-1}$ $\mathrm{s}^{-1}$. As a consequence, reactivity orders for nucleophiles can also be derived from kinetic investigations with highly electrophilic carbenium ions $\left(k_{2}=10^{8}-10^{9} \mathrm{~L} \mathrm{~mol}^{-1} \mathrm{~s}^{-1}\right)$, but the selectivities become smaller in these cases. On the other hand, Figure 3 and Table VII indicate that the linear free energy relationships, derived for slow reactions $\left(10^{-3}-10^{4} \mathrm{~L} \mathrm{~mol}^{-1} \mathrm{~s}^{-1}\right)$, include systems with rate constants of $10^{7}-10^{8} \mathrm{~L} \mathrm{~mol}^{-1} \mathrm{~s}^{-1}$; i.e., selectivities are controlled by the same factors in the whole range from $10^{-3}$ to $10^{8} \mathrm{~L} \mathrm{~mol}^{-1}$ $\mathrm{s}^{-1}$.

Variation of the Alkoxy Group. Alkyl vinyl ethers with primary alkyl groups hardly differ in reactivity (14-16), but tert-butyl vinyl ether (17) is 2.5 times more reactive toward $\left(p-\mathrm{ClC}_{6} \mathrm{H}_{4}\right)_{2} \mathrm{CH}^{+}$than ethyl vinyl ether (14) (Table V). The higher nucleophilicity of 17 compared with 14 has previously been observed in [2+2]cycloaddition reactions with tetracyanoethylene $\left(k_{17} / k_{14}=14\right)^{3 \mathrm{a}}$ and diphenylketene $\left(k_{17} / k_{14}=14\right)$. $\mathrm{sc}$

Comparison of Alkoxy- and Siloxyethylenes. The reactivities of structurally analogous alkoxy- and trimethylsiloxy-substituted CC double bonded systems differ by less than 1 order of magnitude. As shown in Chart I, the reactivity order for alkyl and trimethylsilyl enol ethers may be reverse for different structural types.

Similar nucleophilicities of alkyl and analogously substituted trialkylsilyl vinyl ethers have also been observed with respect to other electrophiles. Tidwell reported trimethylsilyl vinyl ethers to hydrolyse via rate-determining nucleophilic attack on silicon. In contrast, the corresponding tert-butyldimethylsilyl vinyl ethers hydrolyze by initial rate-determining carbon protonation, and for a series of compounds, the methyl ethers 35 were found to be 2.5 times as reactive on average as their tert-butyldimethylsilyl counterparts $36 .{ }^{16}$

$$
\mathrm{R}^{\prime} \mathrm{C}=\mathrm{CH}_{2}
$$

35

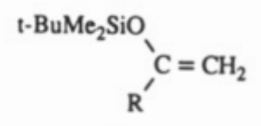

36
Chart II. Comparison of Alkenes, Allylsilanes, and Enol Ethers $\left(\mathrm{CH}_{3} \mathrm{CN}, 20^{\circ} \mathrm{C}\right)$

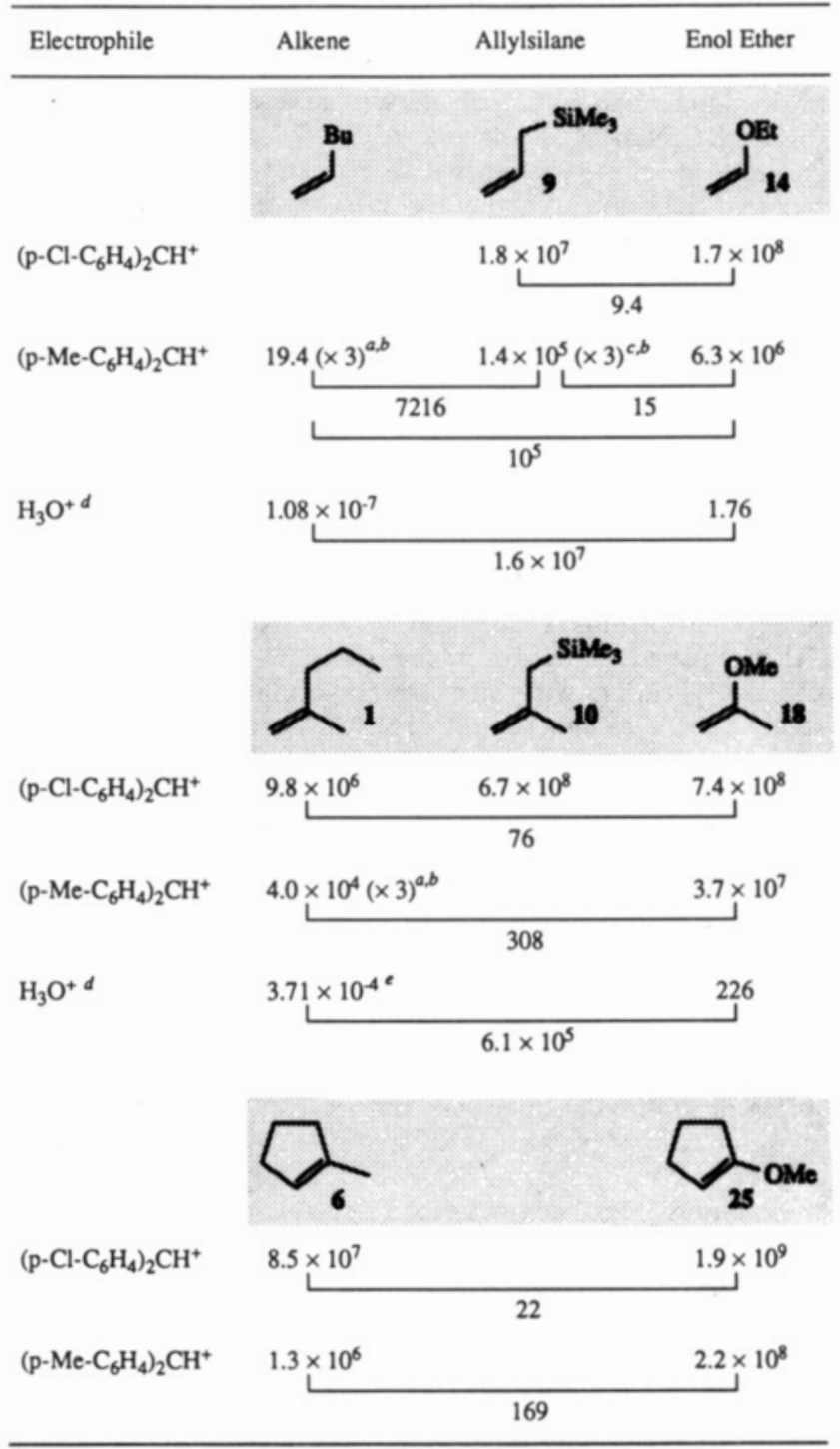

${ }^{a}$ From activation parameters in $\mathrm{CH}_{2} \mathrm{Cl}_{2},{ }^{b}$ Multiplication by 3 accounts for the change $\mathrm{CH}_{2} \mathrm{Cl}_{2} \rightarrow \mathrm{CH}_{3} \mathrm{CN}$. ' From $k_{2}\left(-70^{\circ} \mathrm{C}, \mathrm{CH}_{2} \mathrm{Cl}_{2}\right)$ assuming $\Delta S^{*}=-115 \mathrm{~J} \mathrm{~K}^{-1} \mathrm{~mol}^{-1}$. ${ }^{d}$ From ref $2 \mathrm{a}$. 'Value for isobutene.

Similarly, enol ethyl ethers are slightly more reactive than the corresponding trimethylsilyl ethers (factor 3) in Diels-Alder reactions with the electrophilic nitrosoalkenes. ${ }^{17}$

Comparison of Enol Ethers with Other $\pi$-Nucleophiles. The comparison of 1-hexene and ethyl vinyl ether (Chart II, top) shows

(16) Novice, M. H.; Seikaly, H. R.; Seiz, A. D.; Tidwell, T. T. J. Am. Chem. Soc. 1980, 102, 5835.

(17) Reißig, H.-U.; Hippeli, C.; Arnold, T. Chem. Ber. 1990, 123, 2403. 
Table IX. $\alpha$ - and $\beta$-Methyl Effects in Electrophilic Additions to CC Double Bonds

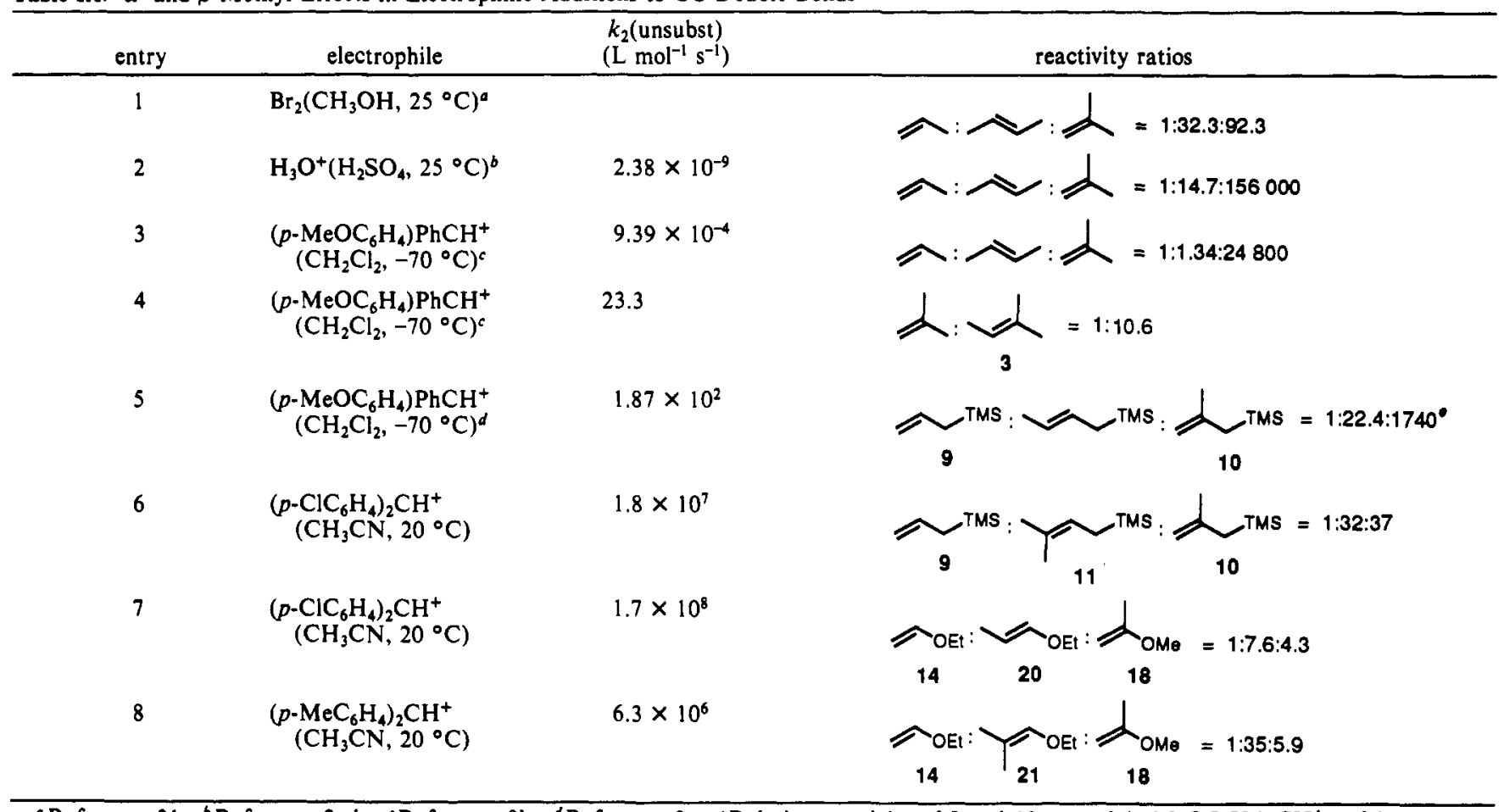

${ }^{a}$ Reference $21,{ }^{b}$ Reference 2a,b. ${ }^{c}$ Reference $9 b$. ${ }^{d}$ Reference $9 e$. ' Relative reactivity of 9 and 10 toward $\left(p-\mathrm{MeOC}_{6} \mathrm{H}_{4}\right)_{2} \mathrm{CH}^{+}$, ref $9 \mathrm{e}$.

that replacement of an alkyl group by ethoxy causes an increase of reactivity by 5 orders of magnitude (reference, (p$\left.\mathrm{MeC}_{6} \mathrm{H}_{4}\right)_{2} \mathrm{CH}^{+}$). This factor decreases to 2 orders of magnitude, when the relative reactivities of 1 and 18 or 6 and 25 toward $\left(p-\mathrm{MeC}_{6} \mathrm{H}_{4}\right)_{2} \mathrm{CH}^{+}$are considered (saturation effect, Chart II).

Even smaller ratios are derived for these two pairs (18/1 and 25/6) when $\left(p-\mathrm{ClC}_{6} \mathrm{H}_{4}\right)_{2} \mathrm{CH}^{+}$is used as the reference electrophile, since then the more reactive component of these couples approaches the diffusion limit. On the other hand, the reactivity ratios of $10^{5}(14 / 1$-hexene) and $300(18 / 1)$, which are observed with respect to $\left(p-\mathrm{MeC}_{6} \mathrm{H}_{4}\right)_{2} \mathrm{CH}^{+}$, can be expected to reflect also the relative reactivities of alkenes and analogous enol ethers toward less reactive carbenium ions, since the rate constants used for these comparisons $\left(k_{2}<5 \times 10^{7}\right)$ fall into the linear section of the log $k_{2} / \log k_{\text {solv }}$ correlations. Greater enol ether:alkene ratios (1.6 $\times$ $10^{7}$ and $6.1 \times 10^{5}$, Chart II) have been reported for $\mathrm{H}_{3} \mathrm{O}^{+}$additions. ${ }^{2 a}$

Alkoxy substituents raise the nucleophilicity of $\mathrm{CC}$ double bonds toward carbenium ions only slightly more than $\mathrm{CH}_{2} \mathrm{Si}\left(\mathrm{CH}_{3}\right)_{3}$ groups (14/9 and $18 / 10$, Chart II). In contrast, ethyl vinyl ether (14) is 18000 times more reactive than allyltrimethylsilane (9) in the stepwise [2+2]-cycloadditions with 2,2-bis(trifluoromethyl)-1,1-dicarbonitrile. 18

The higher nucleophilicity of five-membered-compared with six-membered ring compounds, which has previously been noticed in reactions of benzhydryl cations with cycloalkenes, ${ }^{9 b}$ is also observed in the enol ether series (cf. 22/23 and 31/32, Table V). Accordingly, dihydrofuran (23) has been reported to be more reactive than dihydropyran $(\mathbf{2 2})$ in cycloaddition reactions with tetracyanoethylene, ${ }^{3 \mathrm{a}}$ diphenylketene ${ }^{19}$ and 1,3-dipoles. ${ }^{20}$

Comparison of $\alpha$-and $\beta$-Alkyl Effects. Ruasse, Dubois, and Argile have employed the kinetic effects of $\alpha$ - and $\beta$-methyl groups (see 37) to differentiate bridged and nonbridged transition states in electrophilic additions to alkenes. ${ }^{21}$ The similar magnitudes of $\alpha$-and $\beta$-methyl effects in brominations were interpreted in terms of bridged transition states, while large $\alpha$ - and small (or even inverse) $\beta$-methyl effects, observed for acid-catalyzed hy-

(18) Huisgen, R.; Brückner, R. Tetrahedron Lett. 1990, 31, 2557.

(19) Huisgen, R.; Feiler, L. A.; Otto, P. Chem. Ber. 1969, 102, 3444.

(20) Huisgen, R. In 1,3-Dipolar Cycloaddition Chemistry; Padwa, A., Ed.; Wiley: New York, 1984; Vol. 1, p 1

(21) Ruasse, M. F.; Dubois, J. E.; Argile, A. J. Org. Chem. 1979, 44, 1173. drations, were considered indicative for nonbridged transition states in proton additions (entries 1 and 2, Table IX).<smiles>C=CCO</smiles>

The large $\alpha$ - and small $\beta$-methyl effects, observed for additions of carbenium ions to alkenes, ${ }^{9 b, e, f}$ are thus compatible with unsymmetrical, weakly bridged transition states as derived from stereochemical investigations. ${ }^{22}$

Entries 3, 5, and 8 (Table IX) show that the activation by $\alpha$-methyl groups decreases from 24800 (isobutene/propene) to 1740 (allylsilanes 10/9) and 5.9 (vinyl ethers 18/14) as expected because of the decreasing electron demand in this series. Smaller reactivity ratios for the pairs $10 / 9$ and $18 / 14$ are observed in entries 6 and 7 , as rate constants close to $10^{9}$ are involved.

In contrast, the magnitude of the $\beta$-methyl effect increases with increasing nucleophilicity of the $\pi \cdot$ system (Table IX). While propene and $(E)$-2-butene exhibit similar reactivity (entry 3 ), entries 4 and 5 show that $\beta$-methyl groups now activate by 1 order of magnitude (trimethylethylene/isobutene and crotyltrimethylsilane $/ 9$ ). In the group of vinyl ethers, the $\beta$-methyl effect has overtaken the $\alpha$-methyl effect, and compounds 20 and 21 are more nucleophilic than 18 (entries 7 and 8).

In contrast to these findings, competition experiments with in situ generated carboxonium ions [alkyl $(\mathrm{EtO}) \mathrm{CH}^{+}$] gave the reactivity order $19 \geq 14 \approx 20>21,23$ and protons add faster to 14 (1.76) than to $19(0.476), 20(0.159)$, and 21 (methoxy compound, $\left.0.0252 \mathrm{~L} \mathrm{~mol}^{-1} \mathrm{~s}^{-1}\right)$. $^{2 \mathrm{a}}$

The rate constants for the additions of carbenium ions to alkenes correlate with the stabilities of the carbenium ions produced in the rate-determining step, ${ }^{96}$ and there is no significant correlation between nucleophilic reactivities and ionization potentials of the alkenes. ${ }^{9 f}$ The situation is different for enol ethers: Now the stabilities of the carboxonium ions produced in the addition steps are of minor importance, and Figure 5 shows a fair correlation between rate constants and ionization potentials. This is exactly

(22) Pock, R.; Mayr, H.; Rubow, M.; Wilhelm, E. J. Am. Chem. Soc. 1986, $108,7767$.

(23) Okuyama, T.; Fueno, T.; Furukawa, J. J. Polym. Sci., Part A-1 1969, 7,3045 . 
Chart III. Reactivities of Some Typical Nucieophiles toward $\left(p-\mathrm{CH}_{3} \mathrm{C}_{6} \mathrm{H}_{4}\right)_{2} \mathrm{CH}^{+}$in Acetonitrile at $20^{\circ} \mathrm{C}\left(\log k_{2}\right.$ in Parentheses) ${ }^{a}$

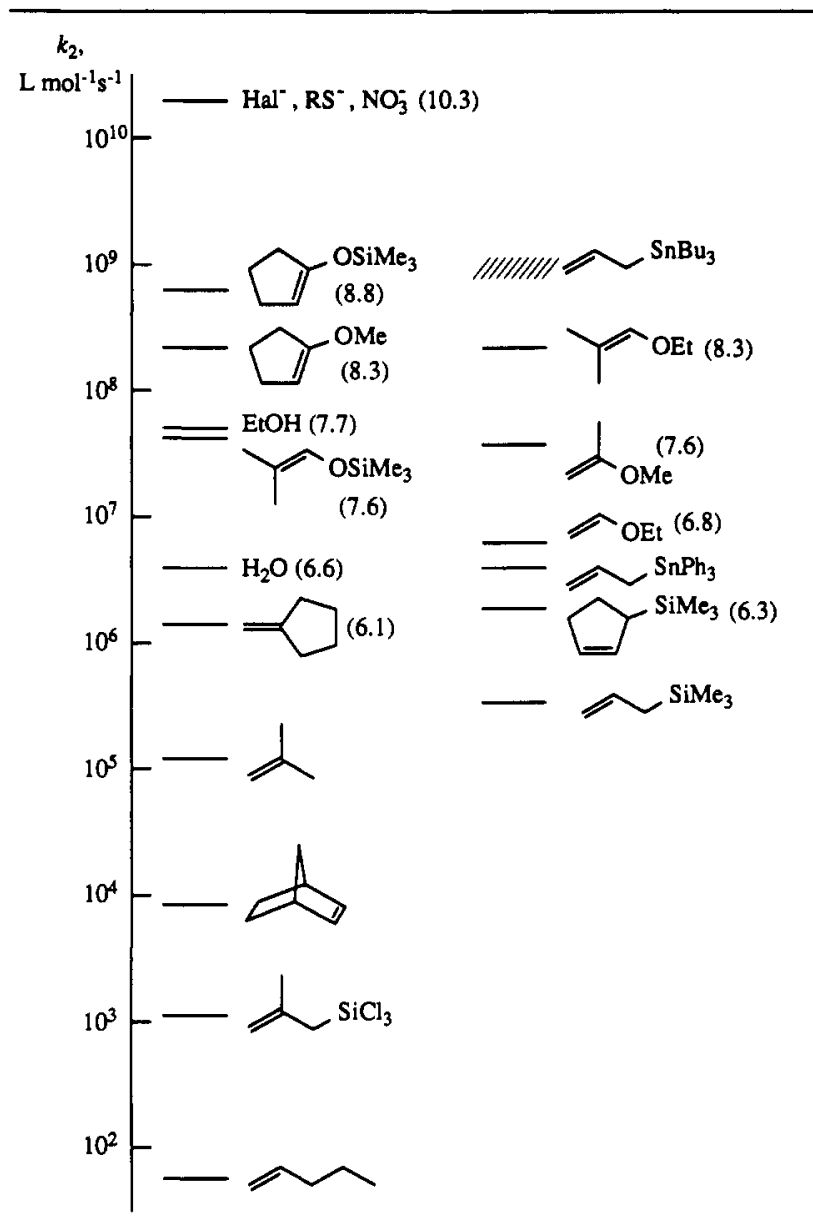

- Entries without numerical values, extrapolations from experiments in $\mathrm{CH}_{2} \mathrm{Cl}_{2}$ assuming $k_{\mathrm{CH}_{3} \mathrm{CN}}: k_{\mathrm{CH}_{2} \mathrm{Cl}_{2}}=3: 1$.

the trend one would expect when one changes from slow reactions with late (productlike) transition states (alkenes) to fast reactions with early (reactantlike) transition states (enol ethers). This interpretation is inconsistent, however, with our previous conclusion that the transition-state structure of such reactions can only be affected by substituents in the immediate proximity of the reaction center. ${ }^{9}$ Kinetic investigations of reactions of enol ethers with less reactive carbenium ions are needed to disentangle this conflict.

\section{Conclusion}

The bis(p-tolyl)carbenium ion $\left[\left(p-\mathrm{CH}_{3} \mathrm{C}_{6} \mathrm{H}_{4}\right)_{2} \mathrm{CH}^{+}\right]$, which has been used to determine the nucleophilicities of enol ethers and n-nucleophiles in this work, has previously been employed for

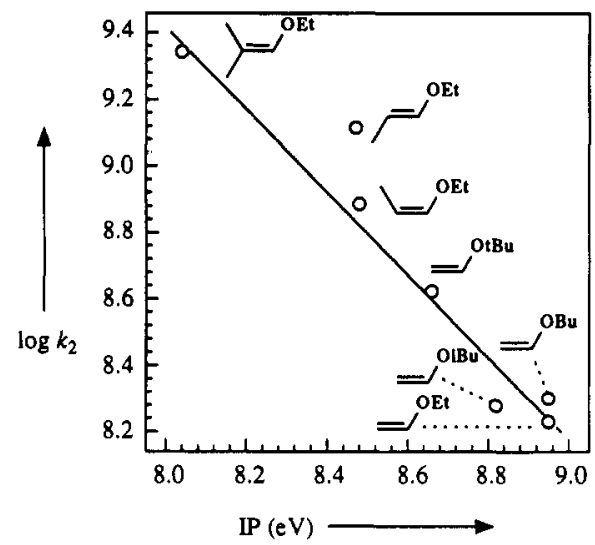

Figure 5. Correlation of the reactivities of various enol ethers toward $\left(p-\mathrm{ClC}_{6} \mathrm{H}_{4}\right)_{2} \mathrm{CH}^{+}$at $20^{\circ} \mathrm{C}$ in acetonitrile with their ionization potentials.

kinetic studies with less nucleophilic alkenes and allylelement compounds. ${ }^{9}$ When these two sets of data are combined, the nucleophilicity scale in Chart III is obtained.

Chart III summarizes that alkoxy-substituted ethylenes are more nucleophilic than alkyl-substituted ethylenes and that their nucleophilicity is comparable to that of alkyl-substituted allylsilanes, water, and alcohols. Since $\log k_{2} / \log k_{\text {solv }}$ correlations, as shown in Figure 4, are linear for $k_{2}$ values from $10^{-4}$ to $10^{8}$ and are parallel for terminal vinyl derivatives, one can assume that the relative reactivities for the enol ethers 14 and 18, the allylsilanes 9 and 10, isobutene, and 1-hexene given in Chart III also reflect their relative reactivities toward less electrophilic carbenium ions. As analogous linear free energy relationships for $\mathrm{n}$-nucleophiles have smaller slopes, ${ }^{7 \mathrm{~b}, 24}$ the relative reactivities of water and alcohols (compared to $\pi$-systems) are expected to grow as the electrophilicity of the carbenium ions decreases. The large values of the rate constants given for the reactions of ( $p$ $\left.\mathrm{H}_{3} \mathrm{CC}_{6} \mathrm{H}_{4}\right)_{2} \mathrm{CH}^{+}$with the enol ethers and many allylsilanes in Chart III imply that all these compounds will undergo diffu. sion-controlled reactions with somewhat more electrophilic carbenium ions. Accordingly, Table $\mathrm{V}$ shows that many reactions of $\left(p-\mathrm{ClC}_{6} \mathrm{H}_{4}\right)_{2} \mathrm{CH}^{+}\left(\mathrm{pK} \mathrm{R}^{+}=-14\right)^{10}$ are getting close to the diffusion limit, and one can extrapolate that carbenium ions with $\mathrm{p} K_{\mathrm{R}}{ }^{+}<-15$ will undergo diffusion-controlled reactions with the nucleophiles listed above water in Chart III. These carbenium ions, which include most alkyl cations, are therefore expected to show zero selectivity in their reactions with enol ethers, allylstannanes, and most of the allylsilanes.

Acknowledgment. We thank Marion Stapper for her dedicated and competent help in many of the rate constant determinations. Generous support by the Deutsche Forschungsgemeinschaft and the Fonds der Chemischen Industrie is gratefully acknowledged.

(24) Ritchie, C. D. Can. J. Chem. 1986, 64, 2239. 